\title{
Prevalence and risk factors of wax moth in bee colonies in the Central and Central-West regions of Burkina Faso: pilot study
}

\author{
Bénéwendé Aristide KABORÉ ${ }^{1,5,6^{*}}$, Barssé COMPAORÉ2, \\ Laibané Dieudonné DAHOUROU ${ }^{3}$, Kiswend-sida Mikhailou DERA ${ }^{1,6}$, \\ Soumaila PAGABELEGUEM ${ }^{1,3}$, Gisèle Marie Sophie OUÉDRAOGO/SANON ${ }^{1}$, \\ Issoufou NANA ${ }^{4}$, Amadou TRAORE ${ }^{5}$ and Adrien Marie Gaston BELEM ${ }^{6}$
}

\begin{abstract}
${ }^{I}$ Direction de la Lutte Intégrée, Insectariumde Bobo-Dioulasso-Campagne d'Eradication de la mouche Tsé-tsé et de la Trypanosomose, Bobo-Dioulasso, Burkina Faso.

${ }^{2}$ Direction régionale des ressources animales et halieutiques du Centre-Ouest, Koudougou, Burkina Faso

${ }^{3}$ Université de Dédougou, Dédougou, Burkina Faso.

${ }^{4}$ Secrétariat technique de l'apiculture, Ouagadougou, Burkina Faso.

${ }^{5}$ Laboratoire de Biologie et Santé Animales (LABIOSA), Département Productions Animales, Institut de l'Environnement et de Recherches Agricoles, Ouagadougou, Burkina Faso.

${ }^{6}$ Institut du Développement Rural, Université Nazi Boni, Bobo-Dioulasso, Burkina Faso.

*Corresponding author ; E-mail : benarist.vet@gmail.com; 01 BP 1087 Bobo 01, Avenue du Gouverneur
\end{abstract}

Louveau, rue 5-37; Tel : +22670343535

Received: 23-02-2021

Accepted: $16-08-2021$

Published: $31-08-2021$

\begin{abstract}
Beekeeping is a very old practice in Burkina Faso and has many advantages, including the availability of honey resources, of endogenous knowledge and support from public policies. However, it faces challenges, including health problems, which are poorly documented. This cross-sectional study was conducted between March and May 2019 in the Central and Central-west regions of Burkina Faso to determine the prevalence and risk factors of wax moth in bee colonies. A total of 200 modern hives were visited of which 106 were colonized or previously colonized. Methods of observation and inspection of the hives were used to search for witnesses of the wax moth infestation: eggs, larvae, pupae cocoons, woven silk cloth, gallery in wax or adult butterflies. A pre-tested questionnaire was used to collect information on beekeepers and apiaries characteristics. An inspection sheet was used to record observations made during the inspection of the hives. The results revealed that the average size was 18 hives by apiary. Hives used were Kenyan, Dadant, and rectangular frame hives with a colonization rate of $53 \%$. The overall prevalence of wax moth was $23.6 \%$ [15.5-31.7\%]. Other predators/pests were observed in $43.4 \%$ of the hives, the main ones being beetles $(25.5 \%)$ and ants $(17 \%)$. The analysis of the radio adjusted odds ratio showed the absence of risk factors among the modalities of the studied variables. In view of the results of this pilot study, more extensive studies could be carried out to have a better understanding of the epidemiology of the infestation and its possible impact that it can have on honey production.
\end{abstract}

(C) 2021 International Formulae Group. All rights reserved.

Keywords: Bee, Beekeeping, Wax moth, Prevalence, Burkina Faso. 


\section{INTRODUCTION}

In Burkina Faso, as in other regions of the world, beekeeping is a very old activity. Once little considered among the animal sectors, beekeeping has become an activity of interest in recent years, providing jobs and foreign currency (MRAH, 2019). Indeed, beekeeping is an important source of income for rural populations (Yédomonhan and Akoègninou, 2009; Birhan et al., 2015) and a means of income diversification (Ahouandjinou et al., 2016). Also, honeybees play an important role in nature through the pollination of various plants (Jonwangwe et al., 2011). The average annual honey production has been estimated at more than 1000 tons of honey in 2018 (MRAH, 2019). In addition, bees participate in maintaining biological diversity and improving agricultural production and productivity through pollination (Bradbear, 2010). The honey sector has many advantages including the availability of wild bee colonies, the availability of honey plants, the existence of beekeeping practices and a growing market (Nombré et al., 2009).

Nevertheless, it faces technical, financial, and sanitary constraints (Nombré, 2003; Kaboré, 2017). In terms of health, infestations of the small beetle (Aethina tumida), the varroa mite (Varroa $s p$.), and the wax moth have been detected in bee colonies in Burkina Faso (Sankara et al., 2015; Aebi et al., 2016).

However, specific investigations on these pathologies have not yet been carried out. The wax moth, which corresponds to part of the development cycle of a butterfly in hives, could be responsible for damage and economic losses such as the destruction of beekeeping equipment (Lalita et al., 2018) and production losses. In case of severe infestation, strong colonies weaken rapidly and weak colonies are sometimes completely destroyed (Ritter and Kencharddi, 2005). In Burkina Faso, wax moth was identified but has not been sufficiently documented to date. Thus, no specific study on the prevalence and the risk factors associated with the infestation has been carried out, which makes it difficult to implement control measures. It is in this context that this prospective study was conducted with the main objective of determining the prevalence of wax moth in bee colonies in the study area.

\section{MATERIALS AND METHODS Study area}

For this pilot study on prevalence of wax moth in Burkina Faso, the Central and Central-west regions were randomly selected among the thirteen (13) regions of the country. They are in the Sudano-Sahelian agro-climatic zone characterized by two (02) seasons including a dry season and a wet season (Thiombiano and Kampmann, 2010). Rainfall in the Central-West varies from $700 \mathrm{~mm}$ to $1200 \mathrm{~mm}$ from the north to the south of the region, while that of the Centre rarely exceeds $700 \mathrm{~mm}$ of water per year. Average temperatures in this Sudano-Sahelian zone are between $20^{\circ} \mathrm{C}$ and $36^{\circ} \mathrm{C}$. Two provinces, three communes and five villages were concerned, considering the availability of beekeepers during the study period and the proximity of the apiaries (Figure 1).

\section{Methodology}

This study was conducted between March and June 2019. Data collection was based on the hive inspection method employed by Kebede et al. (2015). The identification of wax moth eggs, larvae, pupae and adult, as evidence of wax moth infestation was based on the standard wax moth research methods developed by Ellis et al. (2013). An inspection sheet and a questionnaire were used to record inspection results and collect data on apiaries and beekeepers.

A simple random sampling method was used. The possession of barbed or framed hives was considered as a criterion for inclusion in the study. Considering the formula $n=z^{2} p q / e^{2}$ (Cochran, 1963), with an expected prevalence (p) of 90\% (Kientega, 2011), a precision (e) of $5 \%(\mathrm{z}=1.96)$, the minimum sample size was estimated at 138 colonies. But, a total of 106 populated or previously populated hives were inspected according to the availability. 


\section{Statistical analysis}

The data collected at the inspection and from the beekeepers were entered into the Excel spreadsheet and transferred to $\mathrm{R}$ software version 3.2.3 where descriptive and analytical statistical analyses were performed using the Rcmdr package. The $\mathrm{Chi}^{2}$ and/or Fischer's exact test was used to study the relationship between the infestation and some variables. For the identification of risk factors, a two-by-two logistic regression was used to calculate the raw Odds ratio. Then, the variables with a $p$-value of less than 0.2 were integrated into a generalized linear model for the calculation of the adjusted odds ratios. The difference was considered significant if the $\mathrm{p}$ value was less than 0.05 . The QGIS version 2.4 software was used to produce the map of the study area.

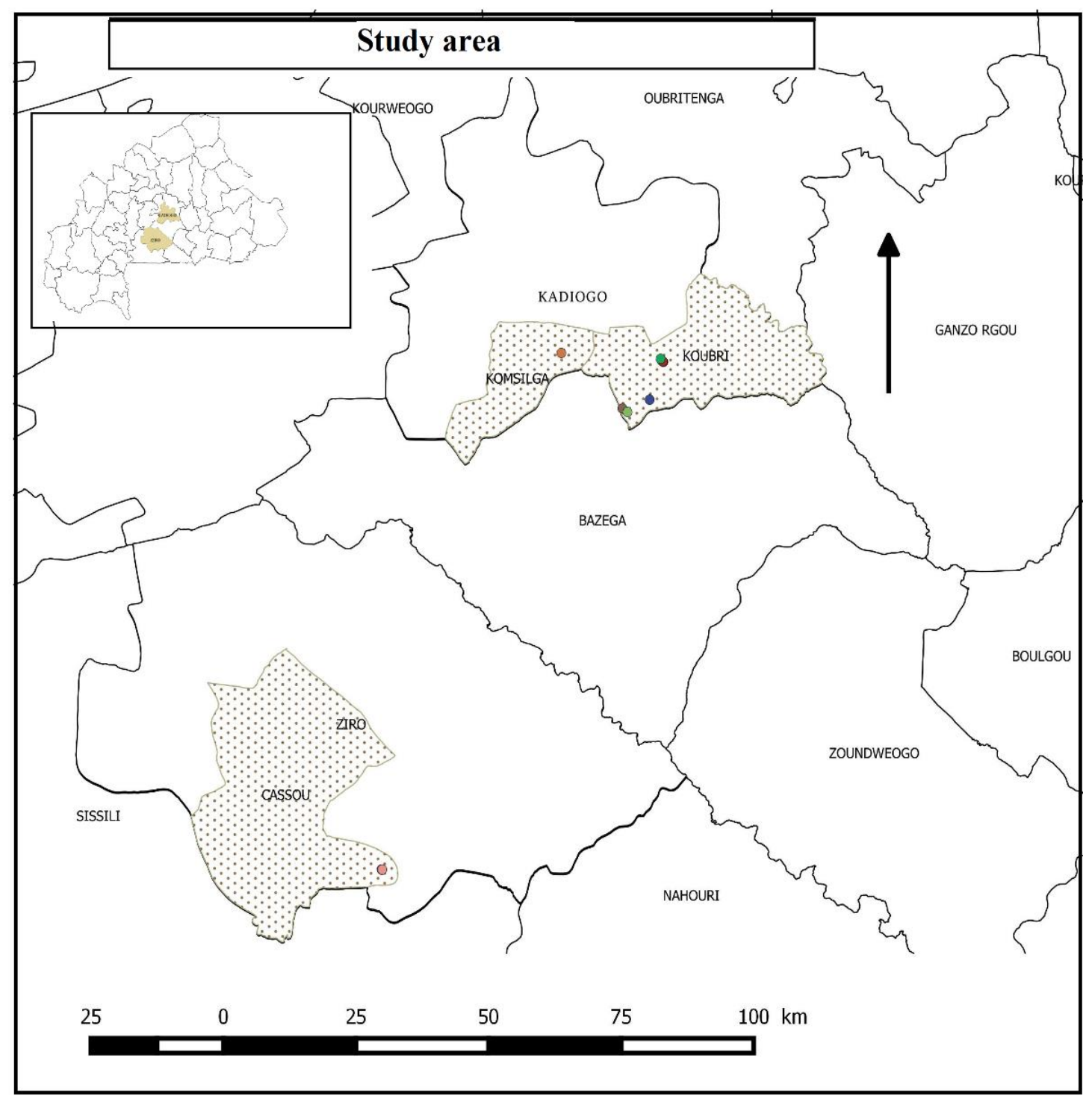

Figure 1: Study area and apiary sites. 


\section{RESULTS}

\section{Characteristics of beekeepers and apiaries}

In the 11 apiaries visited, 200 hives were found with an average size of 18 hives per apiary. The inspection concerned 106 hives among which 93 populated hives and 13 deserted hives. Thus, the colonization rate was estimated at $53 \%$. As for the types of hives used, the Kenyan hive $(70.8 \%)$ was the most dominant, followed by the Dadant hive and the rectangular frame hive (Figure 2).

The hives were mainly prepared by embossing the bars or frames (84.9\%), but some beekeepers practiced in addition to embossing, smoking (15.1\%) with certain plant parts. The hives were placed in $66 \%, 18.9 \%$ and $15.1 \%$ respectively on high relief, swampy and flat land. The averages of parameters such as age of the hives, frequency of visits and harvesting were 7.8 years, and 2 visits per year and 2 harvests/year respectively. Prevalence of wax moth in the study area

\section{Overall prevalence}

During this study, the infestation controls carried on were larvae, pupae, galleries dug in the wax combs, the presence of woven silk cloth or adult butterflies in the hive. On 106 colonized and previously colonized hives, infestation controls were identified in 25 hives, for an overall prevalence of $23.6 \%$ [23.5-23.7\%].

\section{Variation factors associated with wax moth infestation}

The infestation was significantly higher in the Central region $(32.3 \%$ [32.2-32.4\%]) than in the Central-West region $(9.8 \%$ [9.7$9.9 \%]$ ) with a value of $p=0.007$. The variation was also significantly different according to the village (Table 1).

In terms of hive types, the prevalence was significantly higher $(p=0.03)$ in rectangular frame hives $(100 \%)$ than in Dadant (27.6\%) and Kenyan (20\%) types. Finally, according to the controls encountered during hive inspection, larvae and pupae were the most observed (Figure 3).

\section{Other observations made during the inspection of the hives}

Beyond the wax moth, other bee colony enemies were observed in $43.4 \%$ of the hives inspected. Beetles (25.5\%) and ants (17\%) were the most observed enemies (Figure 4).

The prevalence of wax moth varied significantly according to the presence or absence of other enemies ( $p=0.0045)$. In fact, $68 \%$ of the hives infested with wax moth were inhabited by other enemies.

\section{Risk factors for wax moth}

For the study of the risk factors for wax moth infestation of hives, the explanatory variables were region, hive type, apiary site, hive preparation technique, age of the hive, and presence of other pests. The univariate logistic regression results seem to indicate that the region and the presence of other pest influence wax moth infestation with a p-value respectively of 0.012 and 0.006 (Table 2). But the multivariate logistic regression by determining the adjusted odds ratio, used in epidemiology to study the relationship between a disease and several factors shown that there is no risk factor among the studied variables (Table 3). 


\section{Proportions of different types of hives}

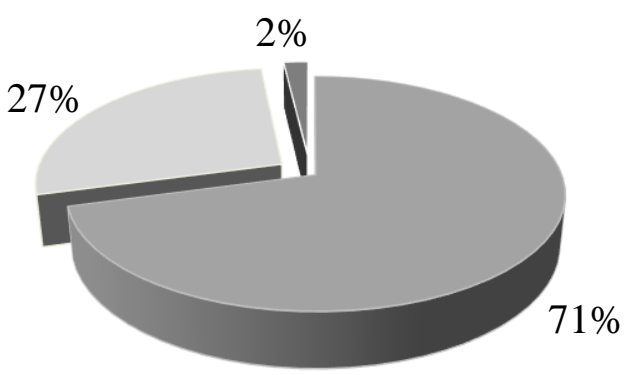

Kenyan Dadant $\quad$ rectangular with frames

Figure 2: Types of hives used in the study apiaries.

Table 1: Prevalence of wax moth according to villages.

\begin{tabular}{lcc}
\hline Villages & Prevalence (\%) and confidence interval at 95\% & p-value \\
\hline Poédogo & $50.0[49.6-50.4]$ & \\
Nakamtenga & $47.8[47.6-48.0]$ & \\
Boulbi & $20.0[17.8-22.2]$ & 0.005 \\
Gomtoaga & $18.8[17.8-19.1]$ & \\
Tare & $9.8[9.7-10.0]$ & \\
\hline
\end{tabular}

Prevalence of infestation according to controls

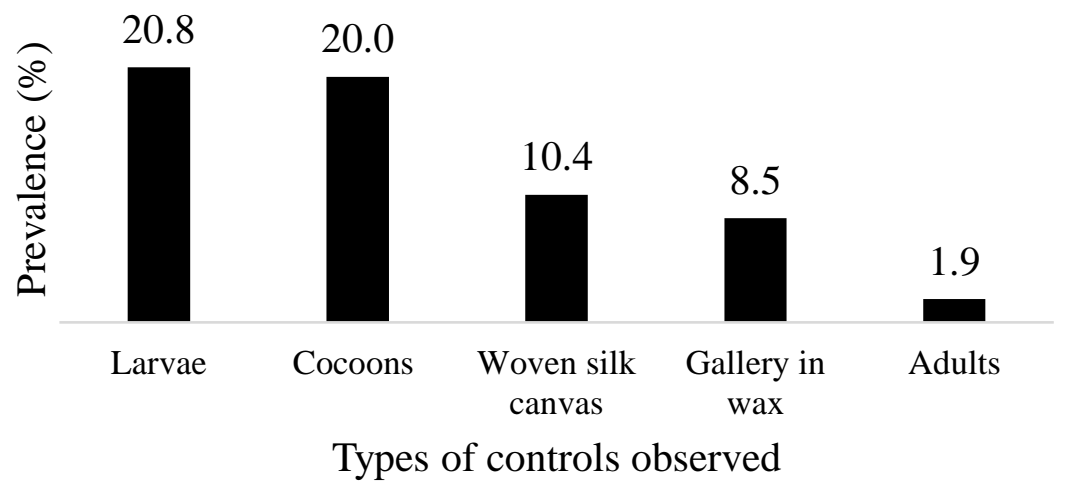

Figure 3: Prevalence of infestation according to controls observed. 
Prevalence of other observed predators/pests

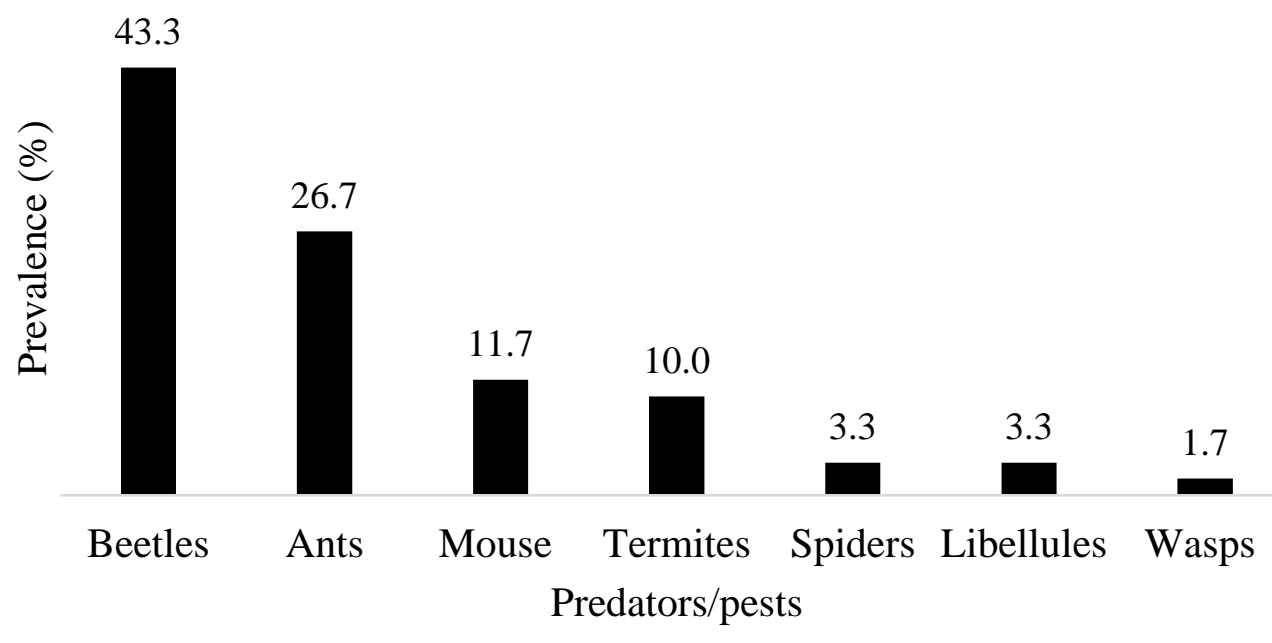

Figure 4: Prevalence of other observed predators/pests.

Table 2 : Univariate Logistic Regression Statistics.

\begin{tabular}{|c|c|c|c|c|}
\hline Variables & Modalities & $\begin{array}{l}\text { Unadjusted } \\
\text { odds ratio }\end{array}$ & $\begin{array}{l}95 \% \text { confidence } \\
\text { interval }\end{array}$ & P-value \\
\hline \multirow[t]{2}{*}{ Region } & Center & 4.14 & $1.39-14.01$ & 0.012 \\
\hline & Central West & Reference & & \\
\hline \multirow[t]{2}{*}{ Type of hive } & Beehives with bars & Reference & & \\
\hline & Beehives with frames & 1.90 & $0.74-4.88$ & 0.180 \\
\hline \multirow[t]{2}{*}{ Apiary sites } & Shaded & 2.19 & $0.87-5.49$ & 0.09 \\
\hline & Dry & Reference & & \\
\hline Preparation of the hive & $\begin{array}{l}\text { Embossing and smoking } \\
\text { Embossing only }\end{array}$ & $\begin{array}{l}0.71 \\
\text { Reference }\end{array}$ & $0.18-2.71$ & 0.622 \\
\hline Age of the hive & Amortized & Reference & & \\
\hline Presence of other pests & $\begin{array}{l}\text { Present } \\
\text { Absent }\end{array}$ & $\begin{array}{l}3.81 \\
\text { Reference }\end{array}$ & $1.46-9.90$ & 0.006 \\
\hline
\end{tabular}

Table 3: Multivariate logistic regression statistics.

\begin{tabular}{lllll}
\hline Variables & Modalities & $\begin{array}{l}\text { Adjusted } \\
\text { odds ratio }\end{array}$ & $\begin{array}{l}\mathbf{9 5 \%} \text { interval } \\
\text { infidence }\end{array}$ & P-value \\
\hline Region & $\begin{array}{l}\text { Center } \\
\text { Central West }\end{array}$ & $\begin{array}{l}3.06 \\
\text { Reference }\end{array}$ & $0.71-13.08$ & 0.13 \\
Type of hive & $\begin{array}{l}\text { Beehives with bars } \\
\text { Beehives with frames }\end{array}$ & $\begin{array}{l}1.73 \\
\text { Reference }\end{array}$ & $0.60-4.95$ & 0.30 \\
& & &
\end{tabular}




\begin{tabular}{lllll} 
Apiary sites & Shaded & 0.94 & $0.31-2.86$ & 0.92 \\
& Dry & Reference & & \\
Age of the hive & Amortized & Reference & & 0.65 \\
& Not amortized & 0.78 & $0.27-2.25$ & \\
Presence of other pests & Present & 2.37 & $0.76-7.42$ & 0.13 \\
& Absent & Reference & & \\
\hline
\end{tabular}

\section{DISCUSSION}

\section{Characteristics of apiaries and beekeepers}

Of the three types of hives encountered, the predominance of Kenyan hives (71\%) observed is like the observations of Kientega (2011) and Kaboré (2017), who found 57.1\% and $94.2 \%$ Kenyan hives in the apiaries of the Hauts-Bassins and Central-West regions, respectively. With the advent of modern beekeeping since the 1980, beekeeping centers were created and projects were implemented with the promotion of modern beekeeping through the popularization of modern techniques and the Kenyan hive (Freytag, 2010). However, the level of use remains variable according to the availability of beekeeping centers or beekeeping projects in the regions. As an illustration, the establishment of the NGO Wendpuiré in the Central-West region contributed to the promotion of modern beekeeping through the organization of trainings in the region and surroundings, in the promotion of modern beekeeping in the region (Freytag, 2010).

Regardless of hive type, the overall hive population rate of $53 \%$ is significantly lower than the results found by Kientega (2011). The author found that in $88 \%$ of villages in classified forests in the southern Sudanian zone, the stand rate was close to $100 \%$. It should be noted that in Burkina Faso, hive colonization is still based on the capture of wild colonies. So, the rate would be influenced by the potential for honey production, notably the availability of wild bee swarms. The classified forest zone studied by Kientega (2011) would constitute an important source of nectar and water resources, and therefore likely to host many bee colonies, in contrast to the Sudano-Sahelian zone of the Centre and Centre-West dominated by savannahs (MEF, 2009). Nevertheless, beekeepers' practices combined with predator/pest and pesticide effects would contribute to reduce the number of colonies (Aebi et al., 2016).

\section{Prevalence and risk factors for wax moth in the study area}

The identification of infested bee colonies in this study confirms the presence of the infestation in Burkina Faso. The presence of wax moth had been reported in tropical areas (Villières, 1987; Leven et al., 2005) and in Burkina Faso by other authors (Nombré, 2003; Kientega, 2011; Aebi et al., 2016). This presence would testify to the ubiquity of the wax moth (Ellis et al., 2013).

The overall prevalence of $23.6 \%$ is much lower than those found by Kientega (2011) in the classified forests of Dindérésso, Kua, Kuinima and the riparian villages in western Burkina Faso (90\%). It is also slightly lower than the prevalence found by Kebede et al. (2015) in modern hives in Ethiopia (27.4\%). There are several reasons for these discrepancies, the most important of which are climatic factors. In fact, in the present study, average monthly temperatures sometimes exceeded $35{ }^{\circ} \mathrm{C}$ while the optimum temperature range for the complete cycle of the wax moth is between 24 and $35{ }^{\circ} \mathrm{C}$ (Charrière and Imdorf, 2004), which would reduce infestations contrary to the zone of classified forests where temperatures do not reach $35^{\circ} \mathrm{C}$ (Kaboré et al., 2017). The rainfall also influences the development cycle of wax moth and are indeed factors in seasonal variations in prevalence (Sohail et al., 2017; Lalita et al., 2018; Kumar and Khan, 2018). In addition, the study conducted by Kientega (2011), involved both modern and traditional hives.

As for the results obtained by Kebede et 
al. (2015), our studies have been conducted during the same periods and under similar temperature ranges, the difference could be related to the type of hives, the most common of which were Kenyan hives. The hives with supers are larger than the Kenyan ones and would cause the existence of unoccupied rays favoring the establishment of the wax moth (Alemayehu et al., 2017). In addition, when harvesting frame hives, the wax combs in the form of empty cells are kept after extraction and returned to the hive, contributing to the aging of the combs that attract the wax moth (Villières, 1987). This particularity of frame hives would justify the fact that the prevalence was significantly higher in frame hives than in top bar hives during our study.

The prevalence found nevertheless remains high in relation to the size of the apiaries and the damage that can be caused by the presence of wax moth. It varied significantly by region and village. The conditions for setting up and management of apiaries with poorly shiny apiaries (Kientega, 2011) would justify this level of prevalence. The level of knowledge of beekeepers varies according to the zone, in connection with insufficient supervision and training (Kaboré, 2017 ) is at the origin of the variations. Thus, poorly identified sites with low nectar sources will lead to scarcity and weakening of colonies, making them vulnerable to infestation (Leven et al., 2005; Alemayehu et al., 2017; Jack and Ellis, 2018). Apiary management characterized by low frequency of visits or late harvests are also factors that cause butterflies to settle in the hives by the appearance of old and unoccupied combs (Charrière and Imdorf, 2004; Kebede et al., 2015).

\section{Other observations made during the inspection of the hives}

During the study of the prevalence of wax moth, the methodology used allowed to note the presence of other pests in the hives such as beetles, ants, mice, termites, etc. Most of these pests had already been reported in various regions of Burkina Faso and in other countries (Sankara et al., 2015; Kientega, 2011; Ahouandjinou et al., 2016). The observed presence of these predators and the level of prevalence would be due to the conditions favorable to their development, associated with the practices of beekeepers (lack of regular visits, exchange of frames or bars between hives, etc.) which would favor their spread. Also, many beekeepers have not a lot of knowledge for bee diseases (Barry et al., 2018). As for the particular case of the hive beetle, the pest is native to Sub-Saharan Africa where it finds favorable conditions for its development and propagation. Also, our study revealed that the presence of the wax moth in hives creates favorable conditions for the development of certain other pests or other diseases (Boucher, 2016) in case it takes hold first, although the reverse is not excluded. These incidental results would constitute new avenues to investigate regarding to the possible impact of these bee enemies on the production and quality of beehive products.

\section{Risk factors}

The study of risk factors through multivariate logistic regression did not identify any risk factors. Our results are different from those of Sohail et al. (2017) who took into account meteorological factors. This could be explained by the fact that the variables studied did not constitute risk factors for wax moth infestation of colonies during this study. Indeed, the appearance and development would be the result of meteorological factors and more precisely the temperature (Sohail et al., 2017). Through the calculation of unadjusted Odds ratios, univariate logistic regression showed region and the presence of other parasites as risk factors. This could be explained by the different knowledge of beekeepers and the weakening of colonies by other parasites (Vidal-Naquet, 2012), thus making them susceptible. However, as much as the wax moth may favor their establishment (Boucher, 2016), so much they may create favorable conditions for the establishment of the wax

\section{Conclusion}

The prevalence of wax moth is relatively high and associated with the presence of other predators/pests in the study 
area. The results show that the conditions necessary for the development of wax moth are present. The level of prevalence suggests an impact on bee colonies and honey production. In perspective, it will be very useful to initiate further investigations over a long period of time and different agro-ecological zones and to evaluate the impact of the infestation on colony life and production. The other bee enemies identified should be study to know their specific prevalence and their impact on wax moth infestation. Already actions of sensitization on the wax moth will have to be initiated with the beekeepers in order to improve the management of their colonies.

\section{COMPETING INTERESTS}

The authors declare that they have no competing interests.

\section{AUTHORS CONTRIBUTIONS}

BAK, BC, DLD, IN, AT et AMGB designed the study; $\mathrm{BAK}$ and $\mathrm{BC}$ collected the data on the field; BAK, BC, DLD and KMD made the statistical analysis and wrote first draft of the manuscript; SP, GMSO, AT and AMGB made observations on the first draft of the manuscript. All the authors contribute to revised the reviewers' corrections.

\section{ACKNOWLEDGEMENTS}

We thank the Technical Secretariat of Beekeeping for facilitating the implementation of this study through its technical support. Our thanks to all the beekeepers who kindly received us in their apiaries.

\section{REFERENCES}

Aebi A, Frésia M, Aebi A. 2016. Vers une apiculture durable au Burkina Faso ? Analyse de l'insertion du projet dans les réalités locales, Instituts d'ethnologie et de biologie Instituts d'ethnologie et de biologie. Rapport de stage. Université de Neuchatel-Centre Ecologique Albert Schweitzer.

Ahouandjinou TB, Yedomonhan H, Adomou AC, Tossou MG, Akoegninou A. 2016. Caractéristiques techniques et importance socioéconomique de l'apiculture au
Nord-Ouest du Bénin : cas de la commune de Cobly. Int. J. Biol. Chem. Sci., 10(3): 1350-1369. DOI: 10.4314/ijbcs.v10i3.35

Alemayehu G, Taye N, Amssalu B, Deselegn B. 2017. Management Practices to Prevent Wax Moth, a Pest of Honeybees in Ethiopia. International Journal of Research Studies in Biosciences (IJRSB), 5(7): 56-59. DOI: 10.20431/23490365.0507008

Barry F, Seck D, Faye O, Mbahin B, Diawara I, Camara B, Ciss I, Bakou SN and Diouf A. 2018. Beekeeping diagnostic in four production basins in Senegal: an analysis of opportunities and weaknesses. Int. J. Biol. Chem. Sci., 12(3): 1186-1198. DOI: https://dx.doi.org/10.4314/ijbcs.v12i3.9

Birhan M, Sahlu S, Getiye Z. 2015. Assessment of Challenges and Opportunities of Bee Keeping in and Around Gondar. Academic Journal of Entomology, 8(3): 127-131. DOI: 10.5829/idosi.aje.2015.8.3.95133

Boucher S. 2016. Maladies des abeilles (2 $2^{\text {ème }}$ édition). Editions France Agricole : Paris

Bradbear N. 2010. Le rôle des abeilles dans le développement rural. Manuel sur la récolte, la transformation et la commercialisation des produits et services dérivés des abeilles. Produits forestiers nonligneux. Food and Agricultural Organization: Rome

Charrière JD, Imdorf A. 2004. Protection of honey combs from moth damage. Swiss Bee Research Centre, Communication Nr. $24,15 \mathrm{p}$.

Ellis J, Graham J, Mortensen A. 2013. Standard methods for wax moth research. Journal of Apicultural Research, 52(1): 1-17. DOI: 10.3896/IBRA.1.52.1.10

Jack CJ, Ellis JD. 2018. Wax Moth Control. ENY121, U.S. Department of Agriculture, UF/IFAS Extension Service, University of Florida, 3p.

Kaboré BA. 2017. Caractérisation socioéconomique et technique de l'apiculture au Burkina Faso : cas de la région du centre-ouest. Mémoire de diplôme de Master Productions Animales et Développement Durable. Ecole Inter- 
Etats des Sciences et Médecine Vétérinaires, Dakar, 32p.

Kaboré B, Kam S, Ouédraogo GW, Bathiébo DJ. 2017. Etude de l'évolution climatique au Burkina Faso de 1983 à 2012 : cas des villes de Bobo-Dioulasso, Ouagadougou et Dori. Arabian Journal of Earth Sciences, 4(2): 50-59. DOI: 2.2017.4.2.50

Kebede E, Redda Y, Hagos Y, Ababelgu N. 2015. Prevalence of Wax Moth in Modern Hive with Colonies in KaftaHumera. Animal and Veterinary Sciences, 3(5): 132-135.

DOI: 10.11648/j.avs.20150305.12

Kientega Y. 2011. Choix des stratégies de vulgarisation pour l'adoption d'une apiculture améliorée et durable. Mémoire : Ingénieur du développement rural. BoboDioulasso, $65 \mathrm{p}$.

Kumar G, Khan MS. 2018. Study of the life cycle of greater wax moth (Galleria mellonella) under storage conditions in relation to different weather conditions. Journal of Entomology and Zoology Studies, 6(3): 444-447.

Lalita P, Yogesh K, Sunita Y. 2018. Seasonal incidence of Greater wax moth, Galleria mellonella Linnaeus in Apis mellifera colonies in ecological condition of Hisar. Journal of Entomology and Zoology Studies, 6(1): 790-795.

Leven L, Boot WJ, Mutsaers M, Segeren P, Velthuis H. 2005. L'apiculture dans les Zones Tropicales (6 ${ }^{\text {ème }}$ édition), série Agrodok $N^{\circ} 32$. Digigrafi : Wageningen

MRAH (Ministère des Ressources Animales et Halieutiques). 2019. Recensement des apiculteurs et caractérisation des exploitations apicoles du Burkina Faso. Rapport définitif, $39 \mathrm{p}$.

Nombré I. 2003. Etude des potentialités mellifères de deux zones du Burkina Faso Garango (Province du Boulgou) et Nazinga (Province du Nahouri). Thèse de Doctorat Unique, Université de Ouagadougou, Burkina Faso, 156p.

Nombré I, Schweitzer P, Sawadogo M, Boussim JI, Millogo-Rasolodimby J. 2009. Assessment of melliferous plants potentialities in Burkina Faso. Afr. $J$. Ecol., 47 (4): 622-629.
Ritter W, Akratanakul P. 2006. Honey bee diseases and pests: a practical guide; FAO: Rome, vol. 4.

Sankara F, Ilboudo ME, M'peindagha Bongo F, Ouédraogo M, Guinko S. 2015. Inventaire et analyse de l'entomofaune vivant avec les colonies d'abeilles, Apis mellifera adansonii Latreille dans la commune de Garango (Burkina Faso). Entomologie Faunistique - Faunistic Entomology, 68: 183-193.

Sohail M, Aqueel MA, Ellis JD, Afzal M, Raza AM. 2017. Seasonal abundance of greater wax moths (Galleria mellonella L.) in hives of western honey bees (Apis mellifera L.) correlates with minimum and maximum ambient temperature. Journal of Apicultural Research, 56(2): 15.

DOI: doi.org/10.1080/00218839.2017.133582 4

Tchuenguem Fohouo FN, Fameni Tope S, Pharaon Mbianda $\mathrm{O}$, Messi $\mathrm{J}$ and Brückner D. 2010. Foraging behaviour of Apis mellifera adansonii Latreille (Hymenoptera: Apidae) on Daniellia oliveri, Delonix regia, Hymenocardia acida and Terminalia mantaly flowers in Ngaoundéré (Cameroon). Int. J. Biol. Chem. Sci., 4(4): 1180-1190.

Thiombiano A, Kampmann D. 2010. Atlas de la Biodiversité de l'Afrique de l'Ouest (Tome II) : Burkina Faso. Projet BIOTA Afrique : Frankfurt/Main.

Villières B. 1987. L'Apiculture en Afrique Tropicale, Dossier « Le point sur », 11, GERT : Paris.

Vidal-Naquet N. 2012. Les maladies de l'abeille domestique d'élevage Apis mellifera L. Bull. Acad. Vét. Tome 165 $\mathrm{N}^{\circ} 4$. http://www.academie-veterinairedefrance.org/

Yédomonhan H, Akoègninou A. 2009. La production de miel à Manigri (Commnue de Bassila) au Bénin : enjeu et importance socio-économique. Int. J. Biol. Chem. Sci., 3(1): $\quad 125-134$. DOI: 10.4314/ijbcs.v3i1.42743. 